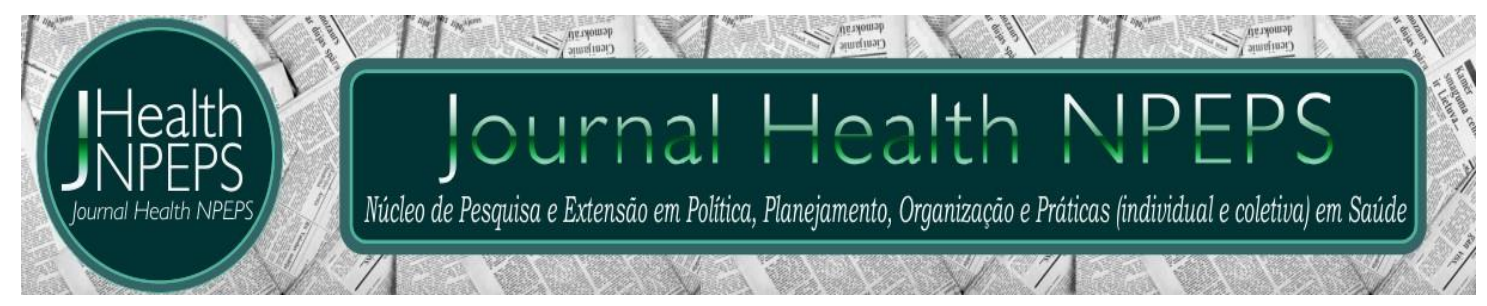

http://dx.doi.org/10.30681/252610104517

EDITORIAL

\title{
Dimensões do cuidado na perspectiva da espiritualidade durante a pandemia pelo novo coronavírus (COVID-19)
}

\section{Dimensions of care from the perspective of spirituality during the new coronavirus pandemic (COVID-19)}

\section{Dimensiones de lo cuidado em la perspectiva de la espiritualidad durante la pandemia debido al nuevo coronavirus (COVID-19)}

\section{Cássia Quelho Tavares ${ }^{1}$}

A espiritualidade, entendida na sua essência como uma dimensão fundamental do ser humano, encontra nos cenários da saúde cada vez mais um lugar inquestionável. Pode-se afirmar que, até a década de 1990, o diálogo entre espiritualidade e saúde encontravam desarmonia e distanciamentos. Com as pesquisas, novas evidências científicas e resultados tangíveis para o cuidado, as aproximações da espiritualidade se tornaram objeto para reconhecimentos.

Soma-se a esta reflexão, nesse momento ímpar de crise sanitária, a pandemia pela COVID-19 que apresenta uma complexa rede de aspectos, relacionadas à estrutura do sistema de saúde, aos suprimentos e insumos basilares à vida, à economia, à realidade da fome, à miséria, ao desamparo, ao abandono social, à invisibilidade das populações de rua, aos refugiados e tantas outras situações de vulnerabilidade social. A insegurança, angústia e medos frente a isso, ressurgem com a possibilidade de contágio/infecção e de morte provocados pelo "inimigo invisível", o novo coronavírus.

\footnotetext{
${ }^{1}$ Enfermeira. Doutora em Teologia Sistemática-Pastoral. Docente Adjunta do curso de Enfermagem e Obstetrícia da Universidade Federal do Rio de Janeiro (UFRJ), Campus Macaé. Líder do Grupo de Extensão e Pesquisa em Espiritualidade e Saúde (GEPESaúde - UFRJ Campus Macaé). Vice-líder do Laboratório de Pesquisa Integrada em Saúde (UFRJ/CNPq). Rio de Janeiro, Brasil. E-mail: cqtavares@hotmail.com. ORCID: https://orcid.org/0000-0002-9033-982X
}

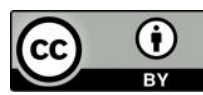

Este artigo está licenciado sob forma de uma licença Creative Commons Atribuição 4.0 Internacional, que permite uso irrestrito, distribuição e reprodução em qualquer meio, desde que a publicação original seja corretamente citada. 
Todos nós, independente de nossas raízes e situações que vivemos, deparamos com a verdade da nossa finitude, que somos mortais e estamos igualados, e quase sempre, impotentes frente aos fenômenos naturais e aqueles ocorridos pela ação do homem.

A morte e o morrer na sociedade contemporânea estão sendo colocados em pauta, apesar do contraditório, é marcado por um "processo de despersonalização que tenta postergar a realidade do sofrimento, do envelhecimento e da morte (...)"1. Nesse contexto, justifica-se a importância da espiritualidade como viés para um processo de ressignificação, diante do gestar e do nascer, nos processos de adoecimento, reabilitação, ressocialização, morte e luto.

Boff $^{2}$ dentre outros teóricos importantes, distinguem espiritualidade de religião. Para Boff, a religião "elabora edifícios teóricos, ritos e símbolos e, por outro lado, sem religião não seria possível o processo palpável da espiritualidade". Todavia, a espiritualidade é intrínseca ao ser humano, e não necessariamente, depende das experiências religiosas e das religiosidades.

Em muitas circunstâncias, percebe-se a falta de clareza conceitual e de aplicabilidade na prática em relação à distinção entre religião e espiritualidade. Esse fator de distinção é fundamental na prática clínica uma vez que a vivência e o respeito pela liberdade religiosa e direito de todos, estão salvaguardados pelas instâncias ético-morais.

A espiritualidade dimensiona e redimensiona o sentido da vida com um dinamismo interno. Em algumas pessoas, há uma maior sensibilidade e autoconsciência acerca de sua espiritualidade, o que favorece os processos de significação e ressignificação dos fatos da vida ${ }^{3,4}$.

No palco clínico-assistencial, reconhece que a espiritualidade compreende e pode definir as relações terapêuticas (cuidador e ser cuidado). Portanto, a espiritualidade é concebida como um componente indispensável para a humanização do cuidado, "que por si só valoriza a alteridade, a liberdade de expressão, a adesão às práticas religiosas enquanto profissão de fé e a solidariedade entre as partes"3.

$\mathrm{Na}$ atualidade, diante da pandemia, a espiritualidade aponta para o sentido da esperança, o poder da resiliência, a reflexão sobre o 
processamento da notícia de testagem positiva e a disposição dos meios internos para esse enfrentamento, a percepção de reencontro das relações interpessoais - família e outros, o reconhecimento da fragilidade e vulnerabilidade individual e coletiva, a reaproximação de culturas, crenças e da própria religião.

Nesse cenário, o profissional de saúde ao desenvolver sua espiritualidade em prol da comunidade, poderá reduzir aflições e pânicos inerentes desse momento e que interferem no entendimento das medidas preventivas/protetivas e na adesão aos cuidados estabelecidos. Além disso, a espiritualidade tende a aumentar no profissional, a atenção e valorização da pessoa, e, consequentemente, com o abandono de vaidades e pretensões individuais, absorve todo sentido de solidariedade, cooperação e do seu juramento profissional a partir da premissa que "amará o teu próximo como a ti mesmo".

Por outro lado, esses profissionais se sentem frustrados, pela impotência frente a falta de recursos suficientes e adequados para o cuidado e pela ocorrência do seu próprio adoecimento ou na observação de adoecimento/óbitos de pares. Esse momento de pandemia, também impõe ao profissional a vivência do cuidado pós morte, particularmente em pessoas que testaram positivo para COVID-19, pois, exige medidas específicas para minimizar o risco de contaminação existente e acalentar o sofrimento da família, desde o acondicionamento ao encaminhamento do corpo. Embora o profissional não consiga atravessar todas essas etapas do cuidado ileso de algum tipo de sofrimento/adoecimento, a manifestação da espiritualidade voltada às forças que abraçam a positividade e a proteção do bem comum favorece o respeito à pessoa e família, e redimensiona os sentimentos de desolação com empatia e doação de si.

A família sente a perda do seu ente querido e não consegue despedir com o afeto e condolências desejadas, pela gravidade do vírus e pelo risco aumentado ao contato e aglomerações tradicionais de velórios e sepultamentos $^{5}$. Nessa circunstância, o profissional deve valorizar as experiências de vida e cultura desses familiares e traçar estratégias que não 
violem medidas sanitárias, mas que permitam a exteriorização da dor e carinho, estando atento e atendendo essas demandas.

A espiritualidade integra várias dimensões do cuidado em saúde. Para tanto, ela deve ser trabalhada visando a promoção do bem-estar da pessoa e família em ambientes assistenciais e comunitários, uma vez que, apresenta-se com um dos principais recursos dos profissionais e sociedade para compreender os sofrimentos e fortalecer a humanidade para novos desafios do século.

\section{REFERÊNCIAS}

1. Tavares CQ. Tanatologia: a ciência da ressignificação da vida. In: CorradiPerini C, Esperandio MRG, Souza W. Biohcs: Bioética e Tanatologia. Série Bioética. Curitiba: CRV; 2020.

2. Boff L. Saber cuidar: ética do humano-compaixão pela terra. Petrópolis: Vozes; 1999.

3. Tavares CQ. Espiritualidade e bioética: prevenção da "violência" em instituições de saúde. Rev Pistis Prax. 2013; 5(1):39-57.

4. Teixeira F. Karl Rahner e as Religiões. 1978. Disponível em: http://www.iserassessoria.org.br/novo/arqsupload/87.DOC. Acesso em: jan 2020.

5. Ministério da Saúde (BR). Secretaria de Vigilância em Saúde. Manejo de corpos no contexto do novo coronavírus COVID-19. Brasília: Ministério da Saúde; 2020.

Como citar este artigo: Tavares CQ. Dimensões do cuidado na perspectiva da espiritualidade durante a pandemia pelo novo coronavírus (COVID-19). J Health NPEPS. 2020; 5(1):1-4. 